\title{
Enhancement of seed germination in stored seeds using different pre-sowing treatments in Bauhinia purpurea $\mathrm{L}$.
}

\author{
M. Hanumantha, Rajesh P. Gunaga ${ }^{1 *}$, Suma S. Biradar, Roopa S. Patil and P. Shankar ${ }^{2}$ \\ College of Forestry, Sirsi Campus/ University of Agricultural Sciences, Dharwad, INDIA \\ ${ }^{1}$ College of Forestry, Navsari Agricultural University, Navsari - 396450 (Gujarat), INDIA \\ ${ }^{2}$ Forest Training Institute, Gungargutti, Dharwad (Karnataka), INDIA \\ *Corresponding author. E-mail: rpgunaga@gmail.com
}

Received: June 27, 2014; Revised received: August 26, 2014; Accepted: November 26, 2014

\begin{abstract}
Bauhinia purpurea L. is one of the important avenue tree species used in garden, road side plantations and other places. Fresh seed produce good germination upto 75 to 100 per cent. Seeds of this species stored for five months produced less germination $(38.00 \%)$ and it could be due to seed dormancy. Hence, the present study was carried out to evaluate different seed treatments to enhance seed germination in stored seeds of $B$. purpurea. Treatment like soaking seeds in hot water for $2 \mathrm{~min}$ to $5 \mathrm{~min}$ followed by overnight soaking in normal water resulted in highest germination of about 59.00 per cent over control (40.00\%). Significant variation for germination parameters such as mean daily germination, germination rate index and germination value as well as early seedling vigour was recorded among different pre-sowing treatments in stored seeds.
\end{abstract}

Keywords: Bauhinia purpurea, Dormancy, Seed germination

\section{INTRODUCTION}

There are about 600 species of Bauhinia distributed in the tropical regions of the World. This genus includes trees, shrubs and vines, which are frequently planted for their attractive pinkish purple flowers and ornamental foliage (Troup, 1983). Bauhinia purpurea L. commonly known as purple bauhinia or orchid tree is native to south-east Asia and usually found in different forest types ranging from evergreen lowland rain forest to mountain forest and savanna as well as scrub and dry deciduous forests to swamp forest (Contu, 2012). It is one of the fast growing species grows up to the height of 35 feet having slender trunks topped with arching branches. Flowers appear during September through November and fruits ripen during January to May (Troup, 1983). The best season of seed collection is April to May depending upon the forest types and climatic features.

Due to various usages like avenue and medicinal properties, plant is called as multipurpose tree species and largely grown as avenue tree in the garden, along the road side. Hence, there is a demand for seedlings of this species (Jha et al., 2006). Considering the conservation of species, there are no known conservation measures for this species; however, the species is currently known to occur in some protected areas. Therefore, samples of seed of B. purpurea need to be collected and stored as an ex situ conservation measure (Contu, 2012). The information generated in this study may be useful in conservation of germplasm of this species. Preliminary germination trial conducted on this species resulted in good seed germination (80 to $100 \%$ ) among different seedlots when fresh seeds collected and sown in the nursery during May to June. However, these seedlings may not be available for planting on the same season, but it can be late planted during late monsoon, especially during August to September. Otherwise seedlings have to be maintained in the nursery for a period of 1 year, so that these seedlings can be planted during rainy season.

In order to overcome these problems, seeds can be stored for a period of six to eight months (APFD, 2014) and then it can be used for sowing in the nursery during November to February for raising seedlings, so that six months maintenance cost and rate of mortality can be reduced. In order to confirm the influence of seed storage on seed germination, a pilot study was undertaken. In this study, seedlot of B. purporea stored in gunny bag for a period of six months was used to test the seed germination in the forest nursery of campus. However, the germination was found to be low. Hence, the present study was undertaken to evaluate the different pre-sowing treatments on germination characteristics and early seedling vigour in Bauhinia purporea in the tropical humid climate region.

\section{MATERIALS AND METHODS}

The present study was undertaken in the campus of Forest Training Institute, Gungargutti, Dharwad, 
Karnataka, India during 2011. Seed materials of Bauhinia purpurea L. were collected from a single tree located in the campus during April 2011. Pods were shade dried for about 10 days and then seeds were extracted and stored in cotton bag for short time. These seeds were exposed to several pre-sowing treatments $\mathrm{T}_{1}$ to $\mathrm{T}_{8}$ along with control $\mathrm{T}_{9}$ (Table 1) and these seeds were sown. Total three replications per treatment $(\mathrm{N}=3 \times 100=300$ seeds $)$ were used and sown them on nursery bed following randomized complete block design during October 2011. Regular watering and weeding was done as and when it requires.

Observation on daily seed germination count was recorded up to 25 days from the date of sowing. Further, these data were subjected to calculate germination per cent, germination rate index, mean daily germination, peak value and germination value for all the pre-seed treatments. Seedling attribute such as seedling height, collar diameter, root length and number of leaves was recorded 20 days after final germination (after 1 $1 \frac{1}{2}$ month of sowing). Further, these seedlings were transplanted into nursery bags containing potting mixture. During this period, 12 seedlings per treatment (4 plants per replication) were uprooted to record moisture content and dry biomass of seedlings (shoot, root, leaf and entire plant biomass) in different treatments. Later, the data were subjected to statistical analysis using mStatc statistical package and ANOVA was constructed for studied parameters. Analysis and separation was also made using arc sine transformation in the case of per cent data.

\section{RESULTS}

B. purpurea is one of the important ornamental and medicinal plant species of India. The general seed germination of this species ranged between 75 and 100 per cent (Navarro and Lezcano, 2008; Yücedağ and Gültekin, 2011). Review showed that seeds of this species can be stored for eight months to one year (Bisht and Ahlawat, 1999). However, during October 2010, seedlot of this species stored for six months were used for raising seedlings in the campus of Forester Training Institute, Gungargutti, Karnataka, India. Further, germination of this seedlot was assessed and it resulted in poor seed germination $(37 \%)$, which was far below than published data (Navarro and Lezcano, 2008; Orwa et al., 2009). Therefore, the present investigation was undertaken to evaluate different physical and chemical based pre-sowing treatments to enhance seed germination in stored seeds (Stored for six months using gunny bag under laboratory condition). Total eight pre-sowing treatments with control were given to seedlots of B. purpurea.

Results showed that there was a significant variation among pre-sowing treatments for seed germination and its attributes such as germination rate index (GRI), mean daily germination (MDG), peak value of germination $(\mathrm{PVG})$ and germination value $(\mathrm{GV}$; Table
1). Seven treatments viz., $\mathrm{T}_{1}, \mathrm{~T}_{2}, \mathrm{~T}_{5}, \mathrm{~T}_{6}, \mathrm{~T}_{4}, \mathrm{~T}_{7}$ and $\mathrm{T}_{8}$ were found to be significantly superior over other two treatments viz. $\mathrm{T}_{3}$ and $\mathrm{T}_{9}$. On the basis of mean value, treatment like soaking seeds in hot water for $2 \min \left(\mathrm{T}_{5}\right)$ and $5 \mathrm{~min}\left(\mathrm{~T}_{6}\right)$ followed by overnight soaking in normal water resulted in highest germination (about $59.0 \%$ ). Other germination parameters also showed highest values in $\mathrm{T}_{5}$ and $\mathrm{T}_{6}$ treatments $(\mathrm{MDG}=2.35$ and 2.65; $\mathrm{PVG}=2.60$ and 2.72 and $\mathrm{GV}=6.1$ and 6.43 ) as compared to other six treatments $\left(\mathrm{T}_{1}, \mathrm{~T}_{2}, \mathrm{~T}_{4}, \mathrm{~T}_{7}, \mathrm{~T}_{8}\right)$. However, the germination rate index (GRI) was found to be highest in treatments- $\mathrm{T}_{7}$ and $\mathrm{T}_{8}$ containing $\mathrm{GA}_{3}$ treatments (Table 1).

The seedling growth attributes like shoot height, collar diameter, root length and number of leaves per plant also recorded significant variation among the nine treatments. Plant height varied from 11.13 to $28.03 \mathrm{~cm}$, whereas root length showed maximum variation, which ranged from 6.6 to $15.0 \mathrm{~cm}$. However, collar diameter (2.89 to $3.42 \mathrm{~mm}$ ) and number of leaves per plant (2.89 to 3.42) also varied among different pre-treatments (Table 2). Interestingly, seed pre-treated with $\mathrm{GA}_{3}$ solution showed better plant height $\left(\mathrm{T}_{7}=21.97 \mathrm{~cm}\right.$ and $\left.\mathrm{T}_{8}=28.03 \mathrm{~cm}\right)$; In contrast, these treatments showed reduced root growth $\left(\mathrm{T}_{7}=6.6 \mathrm{~cm}\right.$ and $\mathrm{T}_{8}=9.10 \mathrm{~cm}$; Table 2) as compared to other treatments.

\section{DISCUSSION}

B. purpurea is one of the fast growing indigenous species and it produces beautiful flowers during September to November and fruit ripens during March to May. Trees standing in the campus produce matured fruits during March to April. Seed is recorded to be orthodox in nature and it can be stored up to 3 years in hermetic storage under room temperature (Orwa et al., 2009). Interestingly, seeds collected during 2010 (one year stored seeds) showed poor seed germination (32\%), when it sown during June 2011. This may be due to lack of seed viability or seed dormancy.

The present study confirmed that seeds stored for short time (about six months) resulted in low germination (40.00\%; Table 1) as compared to fresh seeds sown immediately after collection $(82 \pm 3.2 \%)$. Further, influence of different pre-sowing treatments enhanced seed germination up to 20 per cent (i.e. from 40 to 59 $\%$ at $\mathrm{T}_{9}$ and $\mathrm{T}_{6}$, respectively; Table 1 ). This clearly shows that the low germination in the storage seeds may be due to seed dormancy, but not due to loss of seed viability. In contrast, Navarro and Lezcano (2008) reported that seeds of $B$. purpurea stored in amber glass flasks with semi-airtight lids under cold storage did not significantly affect the seed germination at different time intervals from one month $(100 \%)$ to 12 $(87.33 \%)$ months after storage indicating seeds of this species can be stored with this method; however, there is no information regarding influence of seed storage under control (without cold storage) on germination at different periodic intervals. 
Table 1. Influence of different physical and chemical pre-treatments on seed germination and its attributes in B. purpurea.

\begin{tabular}{lccccc}
\hline $\begin{array}{l}\text { Treatments includes soaking seeds in the } \\
\text { following treatments }\end{array}$ & $\begin{array}{c}\text { Germination* } \\
(\mathbf{\%})\end{array}$ & GRI & MDG & PV & GV \\
\hline $\mathrm{T}_{1}$ : Normal water for 24 hrs. & 53.00 & 37.94 & 2.12 & 2.40 & 5.12 \\
$\mathrm{~T}_{2}$ : Normal water for 48 hrs. & 54.33 & 39.05 & 2.17 & 2.55 & 5.54 \\
$\mathrm{~T}_{3}$ : Hot water for 2 min. & 35.67 & 21.70 & 1.43 & 1.64 & 2.35 \\
$\mathrm{~T}_{4}$ : Hot water for 5 min. & 55.33 & 33.47 & 2.21 & 2.41 & 5.34 \\
$\mathrm{~T}_{5}$ : T3+ overnight soaking in normal water & 58.67 & 40.04 & 2.35 & 2.60 & 6.10 \\
$\mathrm{~T}_{6}$ : T4 + overnight soaking in normal water & 59.00 & 41.48 & 2.36 & 2.72 & 6.43 \\
$\mathrm{~T}_{7}$ : GA3 solution @ 500 ppm for 2 hrs. & 55.67 & 42.35 & 2.23 & 2.54 & 5.69 \\
$\mathrm{~T}_{8}$ : GA3 solution @ 1000 ppm for 2 hrs. & 54.33 & 42.10 & 2.17 & 2.34 & 5.09 \\
$\mathrm{~T}_{9}$ : Control & 40.00 & 21.72 & 1.60 & 1.69 & 2.71 \\
\hline Mean & 51.78 & 35.54 & 2.07 & 2.32 & 4.93 \\
$\mathrm{SEm}$ & 2.54 & 1.98 & 0.10 & 0.12 & 0.43 \\
$\mathrm{CD}$ @ 5\% P & 7.61 & 5.94 & 0.31 & 0.35 & 1.29 \\
\hline
\end{tabular}

*Analysis and separation was made using arc sine transformation for germination (\%)

Table 2. Influence of different physical and chemical pre-treatments seedling attributes in B. purpurea.

\begin{tabular}{lcccc}
\hline $\begin{array}{l}\text { Treatments includes soaking seeds in the } \\
\text { following treatments }\end{array}$ & $\begin{array}{c}\text { Shoot } \\
\text { length }(\mathbf{c m})\end{array}$ & $\begin{array}{c}\text { Collar } \\
\text { diameter }(\mathbf{m m})\end{array}$ & $\begin{array}{c}\text { Root length } \\
(\mathbf{c m})\end{array}$ & $\begin{array}{c}\text { No. of } \\
\text { leaves }\end{array}$ \\
\hline $\mathrm{T}_{1}$ : Normal water for 24 hrs. & 11.73 & 3.02 & 13.67 & 6.40 \\
$\mathrm{~T}_{2}$ : Normal water for 48 hrs. & 11.63 & 3.16 & 13.57 & 6.33 \\
$\mathrm{~T}_{3}$ : Hot water for 2 min. & 11.57 & 3.42 & 14.07 & 7.20 \\
$\mathrm{~T}_{4}$ : Hot water for 5 min. & 11.13 & 3.17 & 13.53 & 6.33 \\
$\mathrm{~T}_{5}$ : T3+ overnight soaking in normal water & 11.37 & 3.02 & 15.00 & 5.40 \\
$\mathrm{~T}_{6}$ : T4 + overnight soaking in normal water & 12.27 & 3.30 & 14.47 & 6.27 \\
$\mathrm{~T}_{7}$ : GA3 solution @ 500 ppm for 2 hrs. & 21.97 & 2.97 & 6.60 & 6.87 \\
$\mathrm{~T}_{8}$ : GA3 solution @ 1000 ppm for 2 hrs. & 28.03 & 3.02 & 9.10 & 6.40 \\
$\mathrm{~T}_{9}$ : Control & 17.37 & 2.89 & 12.90 & 7.60 \\
\hline Mean & 15.23 & 3.11 & 12.54 & 6.53 \\
SEm & 2.40 & 0.10 & 0.72 & 0.24 \\
$\mathrm{CD}$ @ 5\% P & 7.19 & 0.31 & 2.16 & 0.71 \\
\hline
\end{tabular}

Dormancy is reported in many tropical and subtropical species and is classified into seed coat imposed dormancy, embryo dormancy and combination of these two. Seed coat dormancy is predominant in many leguminous members. However, B. purpurea is also a leguminous member that show seed dormancy. In the present study, seeds of $B$. purpurea produced good germination when it sown immediately after collection; however, it showed reduced germination, when it stored for five months in gunny bag. For instance, seeds of non-dormant orthodox tree species such as Acacia drepanolobium, Albizia anthelmintica, A. tanganyicensis, Eucalyptus camaldulensis, Gliricida sepium and Samanea saman germinate within 3 to 14 days (Smith et al., 2002). Whereas species such as Cassia and Delonix have seed coat-imposed dormancy and require some physical or chemical scarification treatment to overcome their dormancy and such species is referred as orthodox species (Smith et al., 2002). Therefore, seeds of this species behave both the features of non-dormant orthodox and pure (dormant) orthodox species.

As per the report of Andhra Pradesh forest department, India, seeds of this species can be stored up to eight months without affecting seed germination. But, it was 12 months of viability with 87 per cent germination within 30 days in this species (Bisht and Ahlawat, 1999). However, in the present study, seed storage affects the seed germination up to 50 per cent and it could be due to influence of seed source on dormancy pattern. Andersson and Milberg (1998) and Meyer and Pendleton (2000) recorded that the intensity of dormancy in a given species exhibits high degrees of variation at several levels such as among populations, within populations and between two fruiting seasons even between seeds collected in different years from 
the same population. Prasad and Nautiyal (1996) and Lopes et al. (2007) reported improvement in seed germination of Bauhinia species through the mechanical scarification and sulphuric acid treatments. It is also reported that seed germination of $B$. purpurea is affected by temperature 25 to $30^{\circ} \mathrm{C}$ (Reino et al., 2008). This clearly shows that seeds of this species may undergo seed dormancy when it stored for longer period. Moreover, climatic situations like hot, humid or moist climate may also influence on seed dormancy.

\section{Conclusion}

It is concluded that germination of stored seed of $B$. purpurea can be improved up to 59.00 per cent using seed treatment i.e., soaking of seeds in hot water for 2 to $5 \mathrm{~min}$ followed by overnight soaking in normal water.

\section{ACKNOWLEDGEMENTS}

We thankful to trainees of Forester, Karnataka Forest Department for their kind help during the study. We also acknowledge the Karnataka Forest Department for kind support.

\section{REFERENCES}

Andersson, L. and Milberg, P. (1998). Variation in seed dormancy among mother plants, populations and years of seed collection. Seed Sci Res, 8: 29-38.

APFD (2014). Bauhinia purpurea. Andhra Pradesh Forest Department (APFD), Retrieved on January 26, 2014 from www.forest.ap.nic.in/silviculture $\% 20 \mathrm{of} \%$ 20species/Forest\%20Seeds/022.htm

Bisht, N.S. and Ahlawat, S.P. (1999). Seed Technology, SFRI, Information Bulletin NO. 7, State Forest Research Institute, Itanagar, Arunachal Pradesh, Pp. 22.

Contu, S. (2012). Bauhinia purpurea. The IUCN Red List of
Threatened Species. Version 2014.2. <www.iucnredlist.org>. Downloaded on 25 August 2014.

Jha, P.K., Dhakal, L.P., Kjær, E.D. and Lillesø, J.B. (2006). Improving productivity of Bauhinia purpurea for tree planting farmers in Nepal. Agrofor Sys, 67 (3): 273-278.

Lopes, J.C., Barbosa, L.G. and Capucho, M.T. (2007). Germinação de Sementes de Bauhinia spp. Floresta, Curitiba, PR, 37(2): 265-274.

Meyer, S.E. and Pendleton, R.L. (2000). Genetic regulation of seed dormancy in Purshia tridentata (Rosaceae). Ann Bot, 85: 521-529.

Navarro, M. and Lezcano, J.C. (2008). Effect of drying method on the longevity and quality of seeds from Bauhinia purpurea. II. Storage in cold-storage room, Pas. y For., 31: 53-61.

Orwa, C., Mutua, A., Kindt, R., Jamnadass, R. and Simons, A. (2009). Agroforestree Database: a tree reference and selection guide version 4.0 (http://www.worldagroforestry.org / af/treedb/).

Prasad, P. and Nautiyal, A.R. (1996). Physiology of germination in Bauhinia: Involvement of seed coat inhibition of germination in B. racemosa seeds. Seed Sci. Tech., 24 (2): 305-308.

Reino, J., Gonzalez, Y. and Sanchez, J.A. (2008). Temperatura óptima de germinación y patrones de imbibición de las semillas de Albizia lebbeck, Gliricidia sepium y Bauhinia purpurea. Pastos y Forrajes, 31(3): 209-216.

Smith, M.T., Ben, S.P. Wang and Msanga, H.P. (2002). Dormancy and Germination, Chapter 5 in Tropical Seed Manual, J.A. Vozzo (Ed.). 149-176. Cited in http:// www. rngr.net/ publications.

Troup, R.S. (1983). Troup's Silviculture of Indian Trees, Vol. IV Leguminosae. Forest Research Institute and Colleges, Dehra Dun, India. Pp. 33-38.

Yücedağ, C. and Cemal Gültekin, H. (2011). The effect of sowing time on germination of twenty two Leguminosae species, African Journal of Agricultural Research, 6 (16): 3809 . 